\title{
Therapeutic revascularisation of ischaemic tissue: the opportunities and challenges for therapy using vascular stem/progenitor cells
}

\author{
Christina L O'Neill', Michelle T O'Doherty', Sarah EJ Wilson', Amer A Rana², Claire E Hirst ${ }^{3}$ Alan W Stitt*1 \\ and Reinhold J Medina'
}

\begin{abstract}
Ischaemia-related diseases such as peripheral artery disease and coronary heart disease constitute a major issue in medicine as they affect millions of individuals each year and represent a considerable economic burden to healthcare systems. If the underlying ischaemia is not sufficiently resolved it can lead to tissue damage, with subsequent cell death. Treating such diseases remains difficult and several strategies have been used to stimulate the growth of blood vessels and promote regeneration of ischaemic tissues, such as the use of recombinant proteins and gene therapy. Although these approaches remain promising, they have limitations and results from clinical trials using these methods have had limited success. Recently, there has been growing interest in the therapeutic potential of using a cell-based approach to treat vasodegenerative disorders. In vascular medicine, various stem cells and adult progenitors have been highlighted as having a vasoreparative role in ischaemic tissues. This review will examine the clinical potential of several stem and progenitor cells that may be utilised to regenerate defunct or damaged vasculature and restore blood flow to the ischaemic tissue. In particular, we focus on the therapeutic potential of endothelial progenitor cells as an exciting new option for the treatment of ischaemic diseases.
\end{abstract}

\section{Background to cell therapy}

Ischaemia is characterised by a reduction in oxygen supply to tissues and organs, usually as a result of blood

*Correspondence: a.stitt@qub.ac.uk

${ }^{1}$ Centre for Vision and Vascular Science, School of Medicine, Dentistry, and

Biomedical Science, Queen's University Belfast, Clinical Sciences Block A, Royal

Victoria Hospital, Belfast BT12 6BA, UK

Full list of author information is available at the end of the article vessel constriction or obstruction. This leads to hypoxia and tissue damage as a consequence of the build up of waste metabolites and may result in cell death [1]. Many important diseases are characterised by acute or chronic ischaemia, which affect millions of people each year and represent a considerable morbidity, mortality and economic cost to healthcare systems worldwide [2].

The use of cell therapy for vascular regeneration offers an exciting new prospect in regenerative medicine. Indeed, in the field of vascular biology there are already a considerable number of ongoing clinical trials using a cytotherapy for ischaemic diseases such as myocardial ischaemia and peripheral limb ischaemia [3,4]. However, the delivery of the correct cell type to the precise area of injury or vascular insufficiency is difficult and many factors need to be considered.

One such factor to consider is efficacy. Cells for vascular therapy must be able to home to ischaemic or damaged tissue and engage in vessel formation alone or in unison with resident vasculature to achieve a controlled and functional reperfusion event, without causing pathological angiogenesis (for example, proliferative retinopathy in the vitreous of the eye).

The timing of delivery and cell numbers also require consideration. A cell therapy approach should be aimed at promoting revascularisation of ischaemic tissue. There is a therapeutic window in which to deliver the cells, to avoid extensive tissue damage, fibrosis and necrosis. The evaluation of the most suitable timing of cell delivery as well as the number of cells needed to integrate into resident vasculature and promote revascularisation of specific tissues requires careful optimisation and evaluation.

A third factor is the administration route. An important point to consider when examining cell recruitment is the mode of cell delivery. Previous studies using vascular progenitor cells have shown that local delivery results in increased homing as the cells are directly delivered to the ischaemic area or tissue environment that is experiencing the disease [5]. A systemic delivery strategy is based on 
the capacity of the cells to be mobilised and directed via chemokines to the ischaemic area; however, the drawback of this approach is that this may result in cells localising to non-target organs such as the liver, kidneys, spleen and lung.

Finally, one should consider cell choice, a critical aspect of any cell therapy. The correct cell must be chosen for its phenotype, cell characteristics and biological functions. This is important, because some ischaemic diseases have added complicating factors such as a hypoxic and proinflammatory microenvironment. In this situation, injecting any cell with the predisposition to switch to an inflammatory phenotype could exacerbate the underlying pathology [6].

Bone marrow $(\mathrm{BM})$ contains a great variety of stem and progenitor cells, such as haematopoietic stem cells (HSCs), mesenchymal stem cells (MSCs) and endothelial progenitor cells (EPCs). BM therefore represents a relevant source of vascular progenitor cells. Clinical trials have tested BM-derived unfractionated mononucleated cells as a therapy for various ischaemic disorders such as heart disease [7]; however, results from these studies have generated conflicting results. This is largely due to the fact that BM contains a heterogeneous mix of cells, making the evaluation of the relative contribution of specific cell types very difficult. Two other accessible sources for isolation of stem/progenitor cells are adult peripheral blood and umbilical cord blood.

There are many cell types currently being considered for cytotherapies in the context of ischaemic diseases (Figure 1). Such cells include MSCs [8], multipotent adult progenitor cells (MAPCs) [9], EPCs [10], pluripotent embryonic stem cells (ESCs) [11], and induced pluripotent stem cells (iPSCs) [12] (Table 1).

The differentiation potential of MSCs and MAPCs into mural cells such as smooth muscle cells (SMCs) and pericytes has been reported [13,14]. Mural cells play a key role in the context of vascular regeneration by providing structural support to the vasculature, and regulating new blood vessel formation, maturation and stabilisation. It has been suggested that building a new blood vessel requires the interaction of both endothelial cells and mural cells. The present review will particularly focus on the endothelial cell component of cytotherapies for vascular regeneration. The three main cell candidates are ESCs, iPSCs and EPCs.

\section{Pluripotent stem cells}

Pluripotent stem cells have generated widespread attention in the last decade due to their capacity to become virtually any cell in the body. With the exception of extraembryonic tissue, pluripotent stem cells have the potential to differentiate into derivatives of all three germ layers.

\section{Embryonic stem cells}

ESCs are derived from the inner cell mass of a preimplantation blastocyst-stage embryo, a process that results in the loss of the embryo. This source presents an ethical dilemma for many, but recent improvements have demonstrated that ESCs can be generated from a single blastomere, without damage to the embryo [15]. Beyond the ethics dimension, there are major concerns about the therapeutic use of ESCs due to an inherent risk of tumour or teratoma formation [16].

Analysis of human ESCs differentiation suggests that endothelial cells originate via a primitive haemangioblast precursor that can give rise to cells of both haematopoietic and endothelial fate [17]. hESC-ECs have been differentiated using a variety of methods, including co-cultures with stromal layers [18] or in suspension culture as embryoid bodies $[17,19]$. These hESC-ECs express a variety of endothelial markers (PECAM1, CD34, KDR and VE-CAD), uptake DiI-Ac-LDL, display the typical cobblestone morphology and form tubes in Matrigel [20]. Transplantation of hESC-ECs has shown that these cells can evoke reperfusion in animal models of hind limb ischaemia [21,22] and ischaemic heart disease, demonstrating their promising therapeutic potential in promoting neovascularisation [23]. However, before these cells can be used as a therapy for patients suffering with ischaemic vascular disease, the generation of immune-compatible transplants needs to be addressed so that clinical application can be realised.

\section{Induced pluripotent stem cells}

Even following the transplantation of closely matched graft cells, a patient is still likely to require immunosuppressive therapy. Autologous cell transplantation is therefore highly desirable to overcome immunogenic mismatch between host and graft.

In 1989, Weintraub and colleagues [24] demonstrated that it was possible to drive fibroblast cell fate into muscle, by expressing the transcription factor MyoD. This phenomenon was later exploited by Takahashi and Yamanaka in mouse fibroblasts [25], and later in human cells to induce the 'reprogramming' of adult skin fibroblasts to a pluripotent state using C-MYC, KLF4, OCT3/4 and SOX2 [26]. These cells, known as iPSCs, have many of the advantages of ESCs, and critically can be generated in a patient-specific manner.

It is possible to differentiate endothelial cells from human iPSCs; differentiation protocols that have been established for human ESCs are applicable to iPSCs. These include, culturing iPSCs with OP9 as feeder cells [27], embryoid body assays [28] and exposure to vascular endothelial growth factor [29]. These culture conditions initiate differentiation to an endothelial phenotype with iPSC-ECs displaying typical endothelial characteristics, 


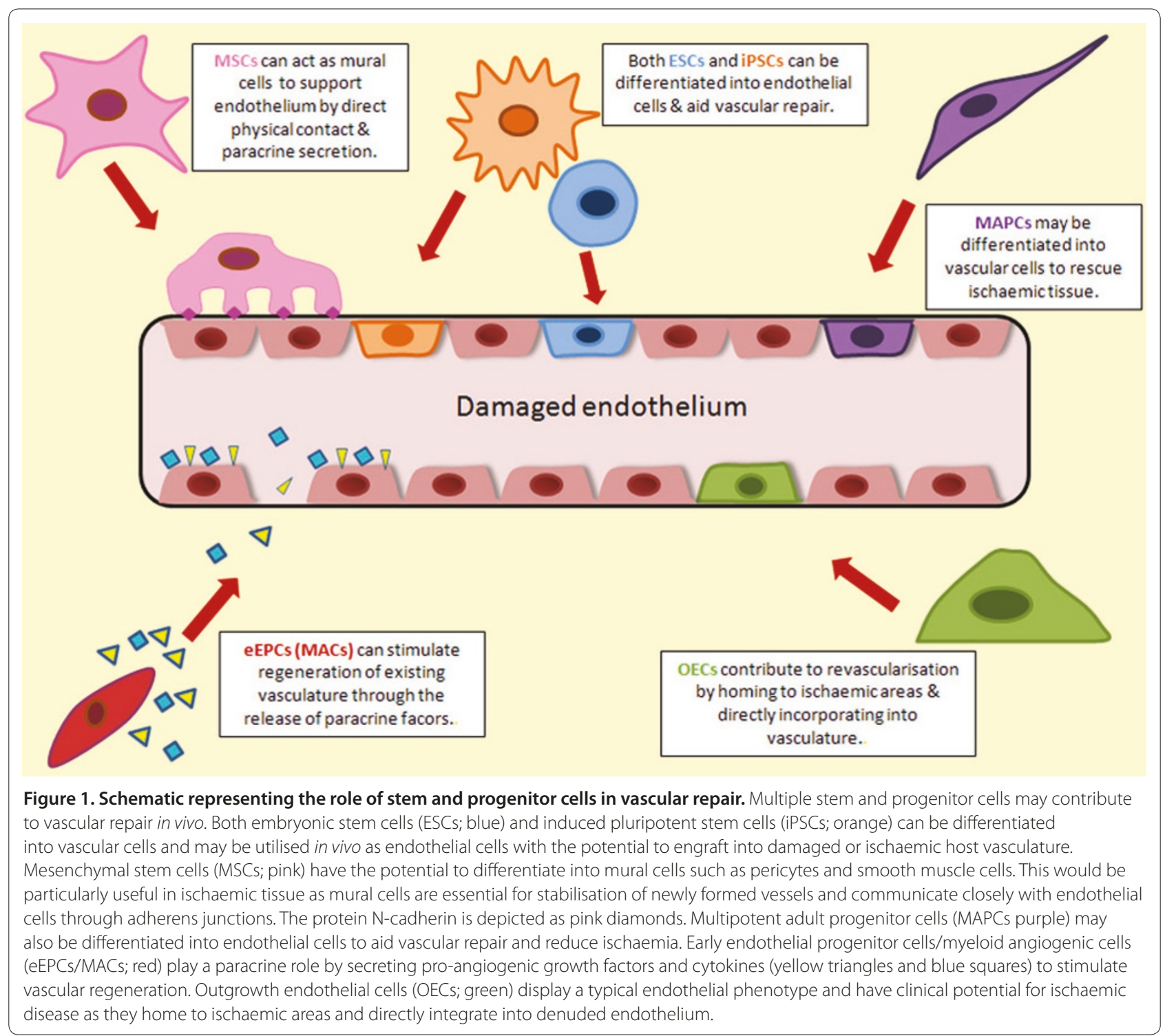

Table 1. Characteristics of stem/progenitor cells that can be used for therapeutic revascularisation of ischaemic tissue

\begin{tabular}{|c|c|c|c|c|}
\hline Cell type & $\begin{array}{c}\text { Proliferative } \\
\text { potential }\end{array}$ & $\begin{array}{c}\text { Risk of } \\
\text { tumour } \\
\text { formation }\end{array}$ & $\begin{array}{c}\text { Capacity to } \\
\text { differentiate } \\
\text { into vascular cells }\end{array}$ & $\begin{array}{l}\text { Engraftment/ } \\
\text { angiogenic } \\
\text { potential in vivo }\end{array}$ \\
\hline \multicolumn{5}{|l|}{ Pluripotent stem cells } \\
\hline Embryonic stem cells & +++ & +++ & + & + \\
\hline Induced pluripotent stem cells & +++ & +++ & + & + \\
\hline \multicolumn{5}{|l|}{ Adult stem cells } \\
\hline Mesenchymal stem cells & + & $+/-$ & ++ & ++ \\
\hline Multipotent adult progenitor cells & ++ & $+/-$ & ++ & ++ \\
\hline \multicolumn{5}{|l|}{ Endothelial progenitor cells } \\
\hline Early endothelial progenitor cells & $+/-$ & + & $+/-$ & + \\
\hline Outgrowth endothelial cells & ++ & $+/-$ & +++ & +++ \\
\hline
\end{tabular}


including capillary formation in Matrigel and expression of endothelial markers such as CD31, KDR, CD144 and endothelial nitric oxide synthase. A recent study has demonstrated the therapeutic potential of iPSCs: when injected into an ischaemic hind limb model, iPSCs were shown to increase capillary density and improve blood perfusion [12].

The past 5 years have seen major advances in the potential translation of iPSCs to the clinic, including improvements in reprogramming efficiencies, alternatives to skin fibroblasts, and integration-free reprogramming transgene expression methods such as adenovirus, minicircle DNA, episomes and synthetic proteins and mRNA [30]. However, several further issues must be resolved before iPSCs can be used clinically. There are concerns with iPSCs regarding the use of the protooncogene c-myc, and insertion mutagenesis due to the use of retroviral sequences. There are also concerns regarding the tumourigenic potential of differentiated PSCs [31]. Additionally, there are issues surrounding the genetic and epigenetic integrity of the iPSCs and also the true nature of their immunogenic status. For example, recent reports have concluded that human iPSCs carry an increased mutational load in the form of karyotypic abnormalities and the accumulation of somatic protein coding point mutations relative the parent cell line used to generate them $[32,33]$. These mutations are presumed to be due to 'reprogramming stresses.' However, in these studies the genomes of clonally derived iPSCs were being compared with reference genomes generated from a polyclonal parent population and therefore, the identification of bona fide mutations could have been hampered. Furthermore, it must be noted that iPSCs appear to retain an epigenetic memory of their former cell type [34]. The influence of this on the differentiation capacity of the iPSCs is not yet clear; for example, persistence of epigenetic memory in iPSCs may be limited during sequential passaging and time in culture. However, this epigenetic memory may be advantageous if we consider deriving iPSCs from vascular cells in order to enhance endothelial cell and smooth muscle cell production from iPSCs.

\section{Adult stem/progenitor cells}

Lineage-committed multipotent or unipotent progenitor cells may represent a more feasible cell choice for the treatment of vascular disease. The benefits of using adultderived progenitors are that they allow for autologous therapy and they are lineage restricted, and thus probably are much safer than pluripotent stem cells with fewer ethical concerns. Many defined populations are already being tested for safety and feasibility in clinical trials, so adult progenitors cells are likely to be the first cells translated to the clinical setting.

\section{Endothelial progenitor cells}

EPCs have been extensively studied as progenitor cells capable of contributing to neovascularisation. These cells may also have potential as diagnostic/prognostic biomarkers for cardiovascular and cerebrovascular disease. There appears to be an inverse correlation between the number of circulating EPCs and the number of deaths from cardiovascular events [35]; furthermore, they can also be used as tools to study vascular disease [36]. EPCs may be isolated from peripheral blood, BM and umbilical cord blood. Although they represent only a minor population $(0.05$ cells $/ \mathrm{ml}$ blood) relative to the cell populations in whole blood, EPCs have been shown to play a major role in therapeutic angiogenesis and vascular repair in various ischaemic tissues; and represent an important candidate for a cell therapy approach [37].

The first putative EPCs were isolated from human peripheral blood in 1997 by Asahara in a seminal paper that appeared to demonstrate postnatal vasculogenesis [38]. This team, lead by Jeffrey Isner, used a combination of cell-sorting approaches, using CD34 as a marker for EPC selection, followed by subsequent plating on fibronectin to isolate EPCs. These cells were found to express endothelial cell-like markers CD31, VEGFR2, Tie-2 and E-selectin after 7 days in culture, indicating their differentiation towards an endothelial phenotype. Importantly, this study also demonstrated functionality; when the pre-labelled EPCs were injected into the ischaemic limbs of nude mice, they appeared to target avascular zones within the diseased tissue and participate in neovascularisation, thus providing evidence of EPCs angiogenic capacity. Since Asahara's discovery, modified versions of this isolation procedure have been used for isolating EPCs [39] and it is now evident that these EPCs are likely to be a heterogeneous mix of endothelial and haematopoietic cells that have been shown to comprise monocytes and macrophages [40].

Over the last decade there have been contradictory reports surrounding the precise nature of EPCs as preclinical and clinical investigations evaluating the therapeutic potential of EPCs have yielded inconsistent results $[10,41]$ This is largely due to the fact that EPCs lack a uniform definition and there are no definitive markers used to isolate an EPC [42]. It is now accepted that there are at least two definitive EPC subsets that can be isolated in vitro. One cell type appears after a few days in culture and these cells are called early EPCs (eEPCs), while the other type of cells, appearing much later, are called outgrowth endothelial cells (OECs) or endothelial colony-forming cells (ECFCs) [37]. The biological properties of these two cells, their potential role in vascular repair and their potential for cytotherapy will be further discussed. 


\section{Early endothelial progenitor cells}

The early EPC population is now generally well recognised not to be endothelial in origin [43]. Although this subset of circulating cells express typical endothelial markers such as CD31, VEGFR2 and Tie2, these markers are not necessarily endothelial specific, and mononuclear cells in culture may acquire these markers through platelet microparticle uptake [44]. Furthermore, eEPCs also express haematopoietic markers CD14 and CD45 and morphologically appear in culture as spindle-shaped cells, with a low proliferative potential, and bear no resemblance to the cobblestone appearance of endothelial cells. Recent research including work from our own laboratory, has demonstrated that early EPCs are distinct from endothelial cells, in terms of their gene expression, proteomic profile and ultrastructure [43]. We have shown that eEPCs represent haematopoietic cells with a molecular fingerprint that resembles pro-angiogenic M2 macrophages [45]. Given all this evidence we feel that the term eEPC is no longer accurate to describe this population of cells, and we recently coined the term myeloid angiogenic cells (MACs) as a more fitting description of the true identity of these cells.

Despite their haematopoietic origin, MACs do have therapeutic value; they appear to stimulate angiogenesis in a paracrine manner [46]. MACs home to areas of ischaemia and stimulate regeneration of existing vasculature through the secretion of pro-angiogenic cytokines and growth factors such as IL-8, hepatocyte growth factor, insulin-like growth factor and granulocyte colonystimulating factor [45,47]. While these cells do not incorporate directly into the vasculature, they remain proximal or loosely attached to the damaged tissue in a perivascular position. In this manner, MACs have been shown to facilitate vascular repair and promote reperfusion in critical limb ischaemia, ischaemic retinopathy and after myocardial infarction [45,48,49]. However, it must be noted that because these cells are linked to macrophages they may be highly plastic, and therefore in the presence of an inflammatory or hypoxic tissue environment they may enhance inflammation [6]. Therefore, careful consideration of the source of the cells and the milieu must therefore be taken into account if these cells are to be used clinically. It may be more advantageous to fully characterise mechanisms responsible for MACs paracrine effects so that respective approaches can be established to promote vascular regeneration. This will include use of conditioned medium, use of recombinant proteins and stimulation of pro-angiogenic pathways.

\section{Outgrowth endothelial progenitor cells}

OECs, also known as ECFCs or late EPCs, represent bona fide endothelial progenitor cells [50]. A classic method for obtaining OECs is in vitro culture of the mononuclear fraction of blood at high density on collagen. Using this method, OEC colonies start appearing from 3 to 5 weeks and bear a typical cobblestone-shaped morphology. Research from our own group using genome-wide transcriptomics, proteomics and ultrastructural evaluation has demonstrated OECs intrinsic endothelial identity. OECs have a remarkably high proliferative capacity in comparison with circulating endothelial cells and maintain an endothelial phenotype with ex vivo long-term expansion [43].

Functionally, OECs display endothelial characteristics. Previous studies have highlighted the in vitro angiogenic potential of OECs; they are capable of integrating into pre-existing vessels and of de novo tube formation in several in vitro models [51,52]. However, a rigorous test for true endothelial potential is direct engraftment in vivo. Various groups, including our own, have demonstrated that OECs possess in vivo potential by directly aiding vascular repair and forming well-perfused vasculature in various in vivo models [51,53]. Recently, we demonstrated OECs therapeutic potential for retinal ischaemia when they were delivered intravitreally into a mouse model and homed specifically to ischaemic areas within the central retina and integrated directly within the host vasculature, assisting in vascular remodelling by forming vascular tubes [54]. Importantly, this study demonstrated functional benefits such as a significant decrease in ischaemia and a concomitant increase in normal vasculature. Although this study examined the therapeutic benefit of OECs over a relatively short time period of 72 hours, the long-term effectiveness and safety of OECs has also been assessed in a porcine model of acute myocardial infarction [55]. Furthermore, OECs injected into the systemic circulation of non-obese diabetic (NOD)/severe combined immunodeficient (SCID) mice are able to lodge and survive in nine different vascular beds for up to 7 months after intravenous tail vein injection, without inducing thrombosis or infarcts [56]. This finding highlights the potential benefits of a novel cytotherapy using a well-defined population of OECs for patients with ischaemic-related pathology.

However, it must be noted that OECs have some limitations when compared with ESCs/iPSCs. Firstly, OECs lack a unique surface marker to identify them, and this limits their isolation using a cell-sorting approach. A panel of surface markers are therefore needed to characterise OECs for expression of endothelial markers such as CD146, VE-cadherin, CD31 and VEGFR2. They also remain a relatively difficult cell to isolate using in vitro culture methodologies. OEC colonies can take quite a long time to emerge, with some colonies taking up to 1 month to appear in culture. Once isolated, however, OEC colonies can be expanded to yield a pure population of 
cells with a high proliferation rate; for example, some cord blood-derived colonies have been expanded up to a level of 80 population doublings in just 90 days.

\section{Conclusion}

There is considerable therapeutic potential in using a cell-based approach to treat vasodegenerative disorders [57]. Indeed, various stem cells and adult progenitors have been highlighted as having important vasoreparative and regenerative potential in vascular medicine [58]. Some of these progenitor cells are already being used in clinical trials for the treatment of ischaemic diseases such as limb and cardiac ischaemia and are showing promising results $[4,59]$. This review has examined the clinical potential of various cell-based therapeutic approaches that may be applied to regenerate defunct or damaged vasculature and restore blood flow. There are many options of which cell types to use, although ultimately the best options will need to be tailored for disease type, for the precise nature of repair or vessel regrowth being sought and for whether the therapeutic regime is autologous or allogeneic. Ideally, once delivered, these cells should have an unambiguous fate with precise reparative and vessel formation properties in vivo whilst having limited replicative potential, thereby reducing the neoplastic risk associated with many stem cell therapies. With a focused research effort in the coming years, there is every expectation that cell therapy can become an important and highly beneficial treatment option for ischaemic disease.

\section{Abbreviations}

BM, bone marrow; ECFC, endothelial colony forming cell; EPC, endothelial progenitor cell; ESC, embryonic stem cell; HSC, hematopoietic stem cell; IL, interleukin; iPSC, induced pluripotent stem cell; MAC, myeloid angiogenic cell; MAPC, multipotent angiogenic progenitor cell; MSC, mesenchymal stem cell; OEC, outgrowth endothelial cell; SMC, smooth muscle cell.

\section{Competing interests}

The authors declare that they have no competing interests.

\section{Acknowledgements}

This work was supported by the Medical Research Council, by Fight for Sight, D.E.L. (NI), by the Juvenile Diabetes Research Foundation, by The Royal Society and by the Sir Jules Thorn Trust.

\section{Author details}

'Centre for Vision and Vascular Science, School of Medicine, Dentistry, and Biomedical Science, Queen's University Belfast, Clinical Sciences Block A, Royal Victoria Hospital, Belfast BT12 6BA, UK. ²Department of Medicine, University of Cambridge, Addenbrookes Hospital, Cambridge CB20 0QQ, UK. ${ }^{3}$ Monash Immunology \& Stem Cell Laboratories, Faculty of Medicine, Nursing \& Health Sciences, Clayton, Victoria 3800, Australia.

Published: 16 August 2012

\section{References}

1. Slovut DP, Sullivan TM: Critical limb ischemia: medical and surgical management. Vasc Med 2008, 13:281-291.

2. Levy E, Gabriel S, Dinet J: The comparative medical costs of atherothrombotic disease in European countries. PharmacoEconomics 2003, 21:651-659.
3. Tongers J, Losordo DW, Landmesser U: Stem and progenitor cell-based therapy in ischaemic heart disease: promise, uncertainties, and challenges. Eur Heart J 2011, 32:1197-1206.

4. Fadini GP, Agostini C, Avogaro A: Autologous stem cell therapy for peripheral arterial disease meta-analysis and systematic review of the literature. Atherosclerosis 2010, 209:10-17.

5. Aicher A, Brenner W, Zuhayra M, Badorff C, Massoudi S, Assmus B, Eckey T, Henze E, Zeiher AM, Dimmeler S: Assessment of the tissue distribution of transplanted human endothelial progenitor cells by radioactive labeling. Circulation 2003, 107:2134-2139.

6. Awad O, Jiao C, Ma N, Dunnwald M, Schatteman GC: Obese diabetic mouse environment differentially affects primitive and monocytic endothelial cell progenitors. Stem Cells 2005, 23:575-583.

7. Hamano K, Nishida M, Hirata K, Mikamo A, Li TS, Harada M, Miura T, Matsuzaki M, Esato K: Local implantation of autologous bone marrow cells for therapeutic angiogenesis in patients with ischemic heart disease: clinical trial and preliminary results. Jpn Circ J 2001, 65:845-847.

8. Toma C, Pittenger MF, Cahill KS, Byrne BJ, Kessler PD: Human mesenchymal stem cells differentiate to a cardiomyocyte phenotype in the adult murine heart. Circulation 2002, 105:93-98.

9. Aranguren XL, Pelacho B, Penuelas I, Abizanda G, Uriz M, Ecay M, Collantaes M, Arana M, Beerens M, Coppiello G, Prieto, I, Perez-Ilzarbe M, Andreu EJ, Luttun A, Prosper F: MAPC transplantation confers a more durable benefit than

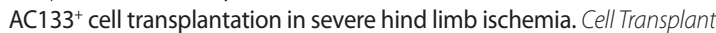
2011, 20:259-269

10. Kalka C, Masuda H, Takahashi T, Kalka-Moll WM, Silver M, Kearney M, Li T, Isner $J M$, Asahara T: Transplantation of ex vivo expanded endothelial progenitor cells for therapeutic neovascularization. Proc Natl Acad Sci U S A 2000, 97:3422-3427.

11. Yamahara K, Sone M, Itoh H, Yamashita JK, Yurugi-Kobayashi T, Homma K, Chao TH, Miyashita K, Park K, Oyamada N, Sawada N, Taura D, Fukunaga Y, Tamura N, Nakao K: Augmentation of neovascularization [corrected] in hindlimb ischemia by combined transplantation of human embryonic stem cellsderived endothelial and mural cells. PloS One 2008, 3:e1666.

12. Rufaihah AJ, Huang NF, Jame S, Lee JC, Nguyen HN, Byers B, De A, Okogbaa J, Rollins M, Reijo-Pera R, Gambhir SS, Cooke JP: Endothelial cells derived from human iPSCS increase capillary density and improve perfusion in a mouse model of peripheral arterial disease. Arterioscler Thromb Vasc Biol 2011, 31:e72-e79.

13. Quevedo HC, Hatzistergos KE, Oskouei BN, Feigenbaum GS, Rodriguez JE, Valdes D, Pattany PM, Zambrano JP, Hu Q, McNiece I, Heldman AW, Hare JM: Allogeneic mesenchymal stem cells restore cardiac function in chronic ischemic cardiomyopathy via trilineage differentiating capacity. Proc Natl Acad SciU S A 2009, 106:14022-14027.

14. Ross JJ, Hong Z, Willenbring B, Zeng L, Isenberg B, Lee EH, Reyes M, Keirstead SA, Weir EK, Tranquillo, Verfaillie CM: Cytokine-induced differentiation of multipotent adult progenitor cells into functional smooth muscle cells. J Clin Invest 2006, 116:3139-3149.

15. Klimanskaya I, Chung Y, Becker S, Lu SJ, Lanza R: Human embryonic stem cell lines derived from single blastomeres. Nature 2006, 444:481-485.

16. Blum B, Benvenisty $\mathrm{N}$ : The tumorigenicity of human embryonic stem cells. Adv Cancer Res 2008, 100:133-158.

17. Zambidis ET, Peault B, ParkTS, Bunz F, Civin Cl: Hematopoietic differentiation of human embryonic stem cells progresses through sequential hematoendothelial, primitive, and definitive stages resembling human yolk sac development. Blood 2005, 106:860-870.

18. Kaufman DS, Hanson ET, Lewis RL, Auerbach R, Thomson JA: Hematopoietic colony-forming cells derived from human embryonic stem cells. Proc Nat Acad SciU S A 2001, 98:10716-10721.

19. Wang ZZ, Au P, Chen T, Shao Y, Daheron LM, Bai H, Arzigian M, Fukumura D, Jain RK, Scadden DT: Endothelial cells derived from human embryonic stem cells form durable blood vessels in vivo. Nat Biotechnol 2007, 25:317-318.

20. Levenberg S, Zoldan J, Basevitch Y, Langer R: Endothelial potential of human embryonic stem cells. Blood 2007, 110:806-814.

21. Sone M, Itoh H, Yamahara K, Yamashita JK, Yurugi-Kobayashi T, Nonoguchi A, Suzuki Y, Chao TH, Sawada N, Fukunaga Y, Miyashita K, Park K, Oyamada N, Sawada N, Taura D, Tamura N, Kondo Y, Nito S, Suemori H, Nakatsuji N, Nishikawa S, Nakao K: Pathway for differentiation of human embryonic stem cells to vascular cell components and their potential for vascular regeneration. Arterioscler Thromb Vasc Biol 2007, 27:2127-2134.

22. Cho SW, Moon SH, Lee SH, Kang SW, Kim J, Lim JM, Kim HS, Kim BS, Chung HM: 
Improvement of postnatal neovascularization by human embryonic stem cell derived endothelial-like cell transplantation in a mouse model of hindlimb ischemia. Circulation 2007, 116:2409-2419.

23. Rufaihah AJ, Haider HK, Heng BC, Ye L, Tan RS, Toh WS, Tian XF, Sim EK, Cao T: Therapeutic angiogenesis by transplantation of human embryonic stem cell-derived $\mathrm{CD} 133^{+}$endothelial progenitor cells for cardiac repair. Regen Med 2011, 5:231-244

24. Weintraub H, Tapscott SJ, Davis RL, Thayer MJ, Adam MA, Lassar AB, Miller AD: Activation of muscle-specific genes in pigment, nerve, fat, liver, and fibroblast cell lines by forced expression of MyoD. Proc Natl Acad SciU U A 1989, 86:5434-5438.

25. Takahashi K, Yamanaka S: Induction of pluripotent stem cells from mouse embryonic and adult fibroblast cultures by defined factors. Cell 2006, 126:663-676.

26. Takahashi K, Tanabe K, Ohnuki M, Narita M, Ichisaka T, Tomoda K, Yamanaka S: Induction of pluripotent stem cells from adult human fibroblasts by defined factors. Cell 2007, 131:861-872.

27. Taura D, Sone M, Homma K, Oyamada N, Takahashi K, Tamura N, Yamanaka S, Nakao K: Induction and isolation of vascular cells from human induced pluripotent stem cells - brief report. Arterioscler Thromb Vasc Biol 2009, 29:1100-1103.

28. Moretti A, Bellin M, Jung CB, Thies TM, Takashima Y, Bernshausen A, Schiemann M, Fischer S, Moosmang S, Smith AG, Lam JT, Laugwitz KL: Mouse and human induced pluripotent stem cells as a source for multipotent $|s| 1+$ cardiovascular progenitors. Faseb J 2010, 24:700-711.

29. Xu Y, Liu L, Zhang L, Fu S, Hu Y, Wang Y, Fu H, Wu K, Xiao H, Liu S, Yu X, Zheng W, Feng B, Huang H: Efficient commitment to functional CD34+ progenitor cells from human bone marrow mesenchymal stem-cell-derived induced pluripotent stem cells. PloS One 2012, 7:e34321.

30. Okita K, Yamanaka S: Induced pluripotent stem cells: opportunities and challenges. Philos Trans R Soc London 2011, 366:2198-2207.

31. Ghosh Z, Huang M, Hu S, Wilson KD, Dey D, Wu JC: Dissecting the oncogenic and tumorigenic potential of differentiated human induced pluripotent stem cells and human embryonic stem cells. Cancer Res 2011, 71:5030-5039.

32. Hussein SM, Batada NN, Vuoristo S, Ching RW, Autio R, Narva E, Ng S, Sourour M, Hamalainen R, Olsson C, Lundin K, Mikkola M, Trokovic R, Peitz M, Brustle O, Bazette-Jones DP, Alitalo K, Lahesmaa R, Nagy A, Otonkoski T: Copy number variation and selection during reprogramming to pluripotency. Nature 2011, 471:58-62.

33. Gore A, Li Z, Fung HL, Young JE, Agarwal S, Antosiewicz-Bourget J, Canto I, Giorgetti A, Israel MA, Kiskinis E, Lee JH, Loh YH, Manos PD, Montserrat N, Panopoulos AD, Ruiz S, Wilbert ML, Yu J, Kirkness EF, Izpisula Belmonte JC, Rossi DJ, Thomson JA, Eggan K, Daley GQ, Goldstein LS, Zhang K: Somatic coding mutations in human induced pluripotent stem cells. Nature 2011, 471:63-67.

34. Kim K, Doi A, Wen B, Ng K, Zhao R, Cahan P, Kim J, Aryee MJ, Ji H, Ehrlich LI, Yabuuchi A, Takeuchi A, Cunniff KC, Hongguang H, Mckinney-Freeman S, Naveiras O, Yoon TJ, Irizarry RA, Jung N, Seita J, Hanna J, Murakami P, Jaenisch R, Weissleder R, Orkin SH, Weissman IL, Feinberg AP, Daley GQ: Epigenetic memory in induced pluripotent stem cells. Nature 2010, 467:285-290.

35. Werner N, Kosiol S, Schiegl T, Ahlers P, Walenta K, Link A, Bohm M, Nickenig G: Circulating endothelial progenitor cells and cardiovascular outcomes. NEngl $J$ Med 2005, 353:999-1007.

36. Medina RJ, O'Neill CL, O'Doherty TM, Wilson SE, Stitt AW: Endothelial progenitors as tools to study vascular disease. Stem Cell Internat 2012:346735.

37. Yoder MC, Mead LE, Prater D, Krier TR, Mroueh KN, Li F, Krasich R, Temm CJ, Prchal JT, Ingram DA: Redefining endothelial progenitor cells via clonal analysis and hematopoietic stem/progenitor cell principals. Blood 2007, 109:1801-1809.

38. Asahara T, Murohara T, Sullivan A, Silver M, van der Zee R, LiT, Witzenbichler B, Schatteman G, Isner JM: Isolation of putative progenitor endothelial cells for angiogenesis. Science 1997, 275:964-967.

39. Hill JM, Zalos G, Halcox JP, Schenke WH, Waclawiw MA, Quyyumi AA, Finkel T: Circulating endothelial progenitor cells, vascular function, and cardiovascular risk. N Engl J Med 2003, 348:593-600.

40. Rohde E, Bartmann C, Schallmoser K, Reinisch A, Lanzer G, Linkesch W, Guelly C, Strunk D: Immune cells mimic the morphology of endothelial progenitor colonies in vitro. Stem Cells 2007, 25:1746-1752.

41. Ziegelhoeffer T, Fernandez B, Kostin S, Heil M, Voswinckel R, Helisch A, Schaper W: Bone marrow-derived cells do not incorporate into the adult growing vasculature. Circ Res 2004, 94:230-238.
42. Ingram DA, Caplice NM, Yoder MC: Unresolved questions, changing definitions, and novel paradigms for defining endothelial progenitor cells. Blood 2005, 106:1525-1531.

43. Medina RJ, O'Neill CL, Sweeney M, Guduric-Fuchs J, Gardiner TA, Simpson DA, Stitt AW: Molecular analysis of endothelial progenitor cell (EPC) subtypes reveals two distinct cell populations with different identities. BMCMed Genom 2010, 3:18.

44. Prokopi M, Pula G, Mayr U, Devue C, Gallagher J, Xiao Q, Boulanger CM, Westwood N, Urbich C, Willeit J, Steiner M, Breuss J, Xu Q, Kiechi S, Mayr M: Proteomic analysis reveals presence of platelet microparticles in endothelial progenitor cell cultures. Blood 2009, 114:723-732.

45. Medina RJ, O'Neill CL, O'Doherty TM, Knott H, Guduric-Fuchs J, Gardiner TA, Stitt AW: Myeloid angiogenic cells act as alternative M2 macrophages and modulate angiogenesis through interleukin-8. Mol Med 2011, 17:1045-1055.

46. Sieveking DP, Buckle A, Celermajer DS, Ng MK: Strikingly different angiogenic properties of endothelial progenitor cell subpopulations: insights from a novel human angiogenesis assay. J Am Coll Cardiol 2008, 51:660-668.

47. Urbich C, Aicher A, Heeschen C, Dernbach E, Hofmann WK, Zeiher AM, Dimmeler S: Soluble factors released by endothelial progenitor cells promote migration of endothelial cells and cardiac resident progenitor cells. J Mol Cell Cardiol 2005, 39:733-742.

48. Urbich C, Heeschen C, Aicher A, Dernbach E, Zeiher AM, Dimmeler S: Relevance of monocytic features for neovascularization capacity of circulating endothelial progenitor cells. Circulation 2003, 108:2511-2516.

49. Assmus B, Schachinger V, Teupe C, Britten M, Lehmann R, Dobert N, Grunwald F, Aicher A, Urbich C, Martin H, Hoelzer D, Dimmeler S, Zeiher AM: Transplantation of Progenitor Cells and Regeneration Enhancement in Acute Myocardial Infarction (TOPCARE-AMI). Circulation 2002, 106:3009-3017.

50. Lin Y, Weisdorf DJ, Solovey A, Hebbel RP: Origins of circulating endothelial cells and endothelial outgrowth from blood. J Clin Invest 2000, 105:71-77.

51. Reinisch A, Hofmann NA, Obenauf AC, Kashofer K, Rohde E, Schallmoser K, Flicker K, Lanzer G, Linkesch W, Speicher MR, Strunk D: Humanized large-scale expanded endothelial colony-forming cells function in vitro and in vivo. Blood 2009, 113:6716-6725.

52. Ingram DA, Mead LE, Tanaka H, Meade V, Fenoglio A, Mortell K, Pollok K, Ferkowicz MJ, Gilley D, Yoder MC: Identification of a novel hierarchy of endothelial progenitor cells using human peripheral and umbilical cord blood. Blood 2004, 104:2752-2760.

53. Hur J, Yoon CH, Kim HS, Choi JH, Kang HJ, Hwang KK, Oh BH, Lee MM, Park YB: Characterization of two types of endothelial progenitor cells and their different contributions to neovasculogenesis. Arterioscler Thromb Vasc Biol 2004, 24:288-293.

54. Medina RJ, O'Neill CL, Humphreys MW, Gardiner TA, Stitt AW: Outgrowth endothelial cells: characterization and their potential for reversing ischemic retinopathy. Invest Ophthalmol Visual Sci 2010, 51:5906-5913.

55. Dubois C, Liu X, Claus P, Marsboom G, Pokreisz P, Vandenwijngaert S, Depelteau H, Streb W, Chaothawee L, Maes F, Gheysens O, Debyser Z, Gillijns H, Pellens M, Vandendriessche T, Chuah M, Collen D, Verbeken E, Belmans A, Van de Werf F, Bogaert J, Janssens S: Differential effects of progenitor cell populations on left ventricular remodeling and myocardial neovascularization after myocardial infarction. J Am Coll Cardiol 2010, 55:2232-2243.

56. Milbauer LC, Enenstein JA, Roney M, Solovey A, Bodempudi V, Nichols TC, Hebbel RP: Blood outgrowth endothelial cell migration and trapping in vivo: a window into gene therapy. Trans/ Res 2009, 153:179-189.

57. Shaw LC, Neu MB, Grant MB: Cell-based therapies for diabetic retinopathy. Curr Diabetes Rep 2011, 11:265-274.

58. Sekiguchi $\mathrm{H}$, Ii M, Losordo DW: The relative potency and safety of endothelial progenitor cells and unselected mononuclear cells for recovery from myocardial infarction and ischemia. J Cell Physio/ 2009, 219:235-242.

59. Losordo DW, Henry TD, Davidson C, Sup Lee J, Costa MA, Bass T, Mendelsohn F, Fortuin FD, Pepine CJ, Traverse JH, Amrani D, Ewenstein BM, Riedel N, Story K, Barker K, Povsic TJ, Harrington RA, Schatz RA; ACT34-CMI Investigators: Intramyocardial, autologous $\mathrm{CD} 34^{+}$cell therapy for refractory angina. Circ Res 2011, 109:428-436.

\section{doi: $10.1186 /$ scrt 122}

Cite this article as: O'Neill CL, et al:: Therapeutic revascularisation of ischaemic tissue: the opportunities and challenges for therapy using vascular stem/progenitor cells. Stem Cell Research \& Therapy 2012, 3:31. 